\title{
Classical Music Styles and Piano Therapy for Patients with Depressive Disorders
}

\section{Estilos de música clássica e terapia com piano para pacientes com transtornos depressives}

\author{
iD (9) Liang Du \\ College of Art, Qinghai University for Nationalities, QingHai, China \\ liang.du086@gmail.com,821525469@qq.com
}

\begin{abstract}
The aim of this study was to investigate the effect of a classical piano music therapy on the level of depression in patients with mild to moderate depressive symptoms. The study was conducted on four groups of random patients, who underwent Beck Depression Inventory surveys on a monthly basis. A significant, 1.5-2.0-fold ( $p=0.001)$, drop in the mean depression score was found in patients after exposure to classical piano music therapy. Listening to classical music is recommended as a means of treatment for mild depressive disorders and as an additional therapy for patients with moderate depression.
\end{abstract}

Keywords: Depressive disorder; Music therapy; Classical music; Black metal.

Resumo: O objetivo deste estudo foi investigar o efeito da musicoterapia com piano clássico no nível de depressão em pacientes com sintomas depressivos leves a moderados. O estudo foi conduzido em quatro grupos de pacientes aleatórios, que passaram por pesquisas do Inventário de Depressão de Beck mensalmente. Uma queda significativa de 1,5-2,0 vezes ( $p=0,001)$ no escore médio de depressão foi encontrada em pacientes após exposição à musicoterapia clássica de piano.

1 Doctor of Philosophy, teacher in the College of art at the Qinghai University for Nationalities in Chengdong District of China; teaching public health and also studying the impact of music on people health. 
Ouvir música clássica é recomendado como meio de tratamento para transtornos depressivos leves e como terapia adicional para pacientes com depressão moderada.

Palavras-chave: Transtorno depressivo; Terapia musical; Música clássica; Black metal.

Submitted on: November 5, 2020

Accepted on: March 17, 2021 


\section{Introduction}

The ever-accelerating pace of society development places increasing demands on individuals (WORLD HEALTH ORGANIZATION, 2018). A busy lifestyle means having many stressful situations. A prolonged exposure to stress can eventually provoke the development of a broad range of diseases, from physical to mental (NGUYEN et al., 2011; HO et al., 2015).

A depressive disorder is one of the most common mental conditions (MIASKOWSKI et al., 2017) that is latent and manifests itself more frequently in people as they become older (SANDADI et al., 2011). In recent years, this condition has been increasingly diagnosed in individuals aged between 10 and 20 years (SULLIVAN et al., 2017). The major challenges posed by this disease are that it is difficult to found in its early stages (SULLIVAN et al. 2018) and that it may result in an act of suicide (BRADT et al., 2016).

There are two groups at risk from a depressive disorder distinguished, adolescents and individuals aged over 45 (LIN et al., 2011). While adolescents have many unsuccessful suicide attempts, older people tend to die on their first (FENG et al., 2018). Such a determined suicidal behavior grows from the feelings of hopelessness, insignificance, and non-satisfaction with one's own achievements. Adolescents, on the contrary, are only growing to become a full-fledged personality. Their bodies undergo hormonal changes that occur in the puberty phase (TSAl et al., 2014). This period is critical for socialization. The quality of life in adulthood depends on how well an individual adjusted to changes that took place in adolescence. These changes are understood as social reorientation and the breakdown of previous relationships, which result in an inner conflict, the mismatch between expectations and the real life (BILGIC and ACAROĞLU, 2017). Frustration that comes along with this conflict eventually results in a mood disorder (CHEN et al., 2018). As it was found, the first symptoms of depression or depressive disorder typically occur at age 14 , among which 8 to 
Classical Music Styles and Piano Therapy for Patients with Depressive Disorders Liang Du

$25 \%$ of onsets are serious but overlooked (BEAULIEU-BOIRE et al., 2013). Out of all patients having a depressive disorder, $21 \%$ continue to feel low throughout life and only $2.5 \%$ of people are diagnosed with it at their first appointment with a psychiatrist (NILSSON, 2011).

Over the last three decades, the incidence of depressive disorders has increased 2 to 3 -fold, especially in developed countries with high-stress levels (KARVINEN et al., 2013). Adolescents with a suspected depressive disorder must be handled with a degree of diagnostic caution, for this age group demonstrates mood swings, often deviant and asocial behavior, and nihilism (THORNTON et al., 2010). The rate of adolescents with depressive symptoms tends to increase with age. For instance, this mood disorder may be found in up to $20 \%$ of individuals aged 14 and older, and $10 \%$ show interest in topics that cause depressive thoughts. Among 15-year-olds, almost half (42\%) experience depression, 18\% have a very low self-esteem, and 7\% have suicidal thoughts (ROBB et al., 2011). This pattern is due to the onset of changes associated with puberty. Depressed adolescents who undergo treatment in a clinical setting are mostly male (LAl et al., 2012). The ratio of suicide thoughts to suicide attempts to suicide is 100: 10: 1. By statistics, over 1 thousand young people die by suicide in the world every day and this number doubled over the past 10 years (BAGRI et al., 2016).

Overall, individuals diagnosed with a depressive disorder have an unrealistic or distorted perceptions of reality. There is more, depressive and suicidal thoughts may intensify and dominate thinking with neuropsychic maladaptation (MCCLEAN et al., 2012). Hence, depression and stress are a precondition of suicide (KOELSCH, 2014; LAFÇI and ÖZTUNÇ, 2015; BRO et al., 2018; SIHVONEN et al., 2017).

In adolescence, stress and depression take roots in the social setting, growing from family conflicts, poor learning performance, and low self-esteem (TRIMBLE, 2012). Depressive conditions are frequently treated with the use of medications (pharmacotherapy), 
Classical Music Styles and Piano Therapy for Patients with Depressive Disorders Liang Du

e.g., antidepressants and serotonin reuptake inhibitors (COULTON et al., 2015). This approach is not necessarily productive, as some drugs may have negative side effects (DAYKIN et al., 2018), and is good for patients with severe affective disturbances. Group and individual psychotherapy methods are also commonly addressed (FERRERI et al., 2014). Given the shortage of effective methods for the treatment of depressive disorders, it is still relevant to seek alternatives, such as music therapy, which has been gaining popularity in recent years (WERNER et al., 2009; BOTTIROLI et al., 2014).

Therecent decades have been a fruitful period for advancements in music production. People received more opportunities to add to the diversity of music genres and the line between different styles of music blurred. The role of music in a person's daily living thus grew but its effect on mental health may be different for each individual (ALBORNOZ, 2011). Music is the most affordable means of therapy that may be found in every house and which can help improve one's mental state and overall performance (DESHMUKH et al., 2009; AALBERS et al., 2017; JORET et al., 2017; ENAIZAN et al., 2020). Attention paid to the music therapy research is, however, insufficient and embraces the effects of passive/ active listening on the psychophysiological state of a person and electroencephalographic screening (STURM et al., 2015; DI LIBERTO et al., 2018).

Music evokes many emotions in those listening to it and can bring up both positive and negative emotional states (MIENDLARZEWSKA and TROST, 2014). Thus, music may serve as a noninvasive instrument of treatment and costs little (CONG et al., 2012a). Different styles of music inflict positive to negative effects upon a healthy person during the music therapy session (CONG et al., 2012b). Some of these styles are underestimated as therapeutic agents (DI LIBERTO et al., 2015), classical music specifically. The young people of today give preferences to fast and aggressive rhythms, which tend to worsen their depressive symptoms.

Music therapy is normally used to treat mild to moderate depressive disorders (BIDELMAN and ALAIN, 2015). Yet, it may show 
Classical Music Styles and Piano Therapy for Patients with Depressive Disorders Liang Du

different results in treating depressed individuals depending on the choice of music (ZENDEL and ALAIN, 2014). Studies on the effect of different styles of music on the human health and mind (BUGOS et al., 2007, 2016; AMERICAN MUSIC THERAPY ASSOCIATION, 2011) report adverse consequences of listening to modern music such as heavy metal, hip-hop and techno in depressed and anxious individuals (CHA et al., 2014). Other styles such as folk music or classical music had a beneficial effect by contrast (ZHANG et al., 2016).

There are a few comprehensive studies on the novel approaches in music therapy used in the treatment of other health issues (SCHOLZ et al., 2016). In parallel to major findings, they revealed that music, including classical, has a strong influence on the human mind (VAN DER MEULEN et al., 2014). However, there is a gap in the knowledge of how long-term and regular music listening sessions affect the mind of depressed patients. Among works devoted to classical music, none examine the influence of its individual styles, e.g., piano styles, on the health of patients with mood disorders.

This work aims to evaluate the therapeutic effect of classical piano music styles on the emotional state of patients with mild to moderate depressive disorders undergoing regular and long-term music therapy.

\section{Materials and Methods}

\section{Research design and sample}

A randomized study on four groups of patients was conducted in 2018 in the Psychiatric Clinic No. 5, QingHai, China. The first group included 35 patients with mild depressive disorders who attended music therapy sessions at the clinic. The second group consisted of 42 patients with moderate depressive disorders. The control group included 50 people without mood disorders and other mental illnesses. The challenged group consisted of 27 
Classical Music Styles and Piano Therapy for Patients with Depressive Disorders Liang Du

people who underwent no treatment and were exposed to extreme music, i.e., black metal (Shining, Burzum, Satyricon, etc.). The first and second groups were asked to listen to classical piano music (Beethoven, Chopin, Tchaikovsky and Mozart) one hour, twice a week, for a year. For comfort, patients were offered headphones and individual listening rooms with dimmed light levels. The music was exclusively instrumental, since the message of the lyrics could distort the results of the study. The third and fourth groups were not exposed to classical music. All patients signed the informed consent to participate in the study. Data on the age and gender composition of the research population are presented in Table 1.

Table 1 - Age and Gender Distribution of Patients within Groups

\begin{tabular}{c|c|c|c|c}
\hline Group & Males, \# & Females, \# & Mean age, males & Mean age, females \\
\hline Mild depression & 20 & 15 & $16.1 \pm 2.4$ & $15.9 \pm 2.6$ \\
\hline Moderate depression & 22 & 20 & $15.5 \pm 2.1$ & $15.8 \pm 1.9$ \\
\hline Control & 24 & 26 & $16.4 \pm 1.9$ & $16.2 \pm 1.5$ \\
\hline Challenged & 20 & 7 & $16.5 \pm 2.8$ & $15.8 \pm 2.1$ \\
\hline \multicolumn{5}{c}{ Source: Own development }
\end{tabular}

Data in the table above show that all groups are comparable in age and gender composition to each other. The fourth group included mostly men, who constitute the major audience of black metal music. All patients did not receive any medication during the observation period. Once a month, patients were screened for depression with a Beck Depression Inventory or BDI (cutoffs: 0 to 9 for normal range; 10 to 15 for mild depression; 16 to 19 for borderline clinical depression; 20 to 29 for moderate depression; 30 to 63 for severe depression).

\section{Statistical analysis}

Statistical data were processed my means of Past, v. 3.0. An independent t-test was used to determine if there is a significant 
Classical Music Styles and Piano Therapy for Patients with Depressive Disorders Liang Du

difference two groups. Differences were considered significant at $p=0.05$ (baseline). Different significance levels were discussed separately.

\section{Results and Discussion}

Statistically significant differences between groups were found at all stages of the study (Figure 1).

\section{Figure 1 - Mean BDI scores in research groups \\ MEAN BECK DEPRESSION INVENTORY SCORES}

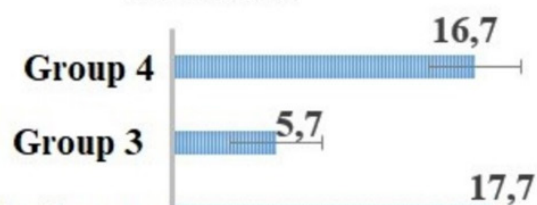

\section{Group 2, post music therapy 17,7}

Group 2, prior music therapy

Group 1, post music therapy

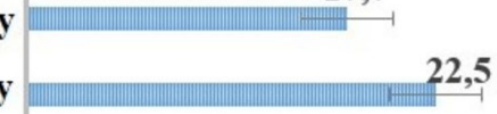

Group 1, prior music therapy
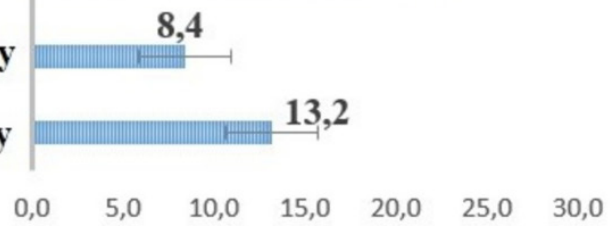

Source: Own development

Note: figure contains means and standard errors of the mean.

The challenged group scored 3.0 times higher than normal controls $(p=0.001)$ and reached the zone of a second group after the music therapy. Moreover, the fourth group scored 1.26-fold higher than the first group before therapy $(p=0.05)$ and twofold higher than the first group after therapy. Difference between the second group before music therapy and the fourth group was 4.8 points with the second group scoring higher.

Differences within the first and second groups before and after therapy turned out to be significant. After the music therapy, the mean depression score in the first group decreased 1.57-fold $(p=$ 
Classical Music Styles and Piano Therapy for Patients with Depressive Disorders Liang Du

0.01), reaching the normal range. The second group demonstrated a similar trend with a mean depression score falling to a point 1.27 times lower, as compared to a before-treatment score value $(p=0.05)$. The mean score of patients in the second group fell within the range for moderate depression. Thus, music therapy significantly reduced the level of depression. In a number of instances, the study showed significant gender differences (Figure 2).

Figure 2 - Gender-sensitive distribution of mean BDI scores within research groups

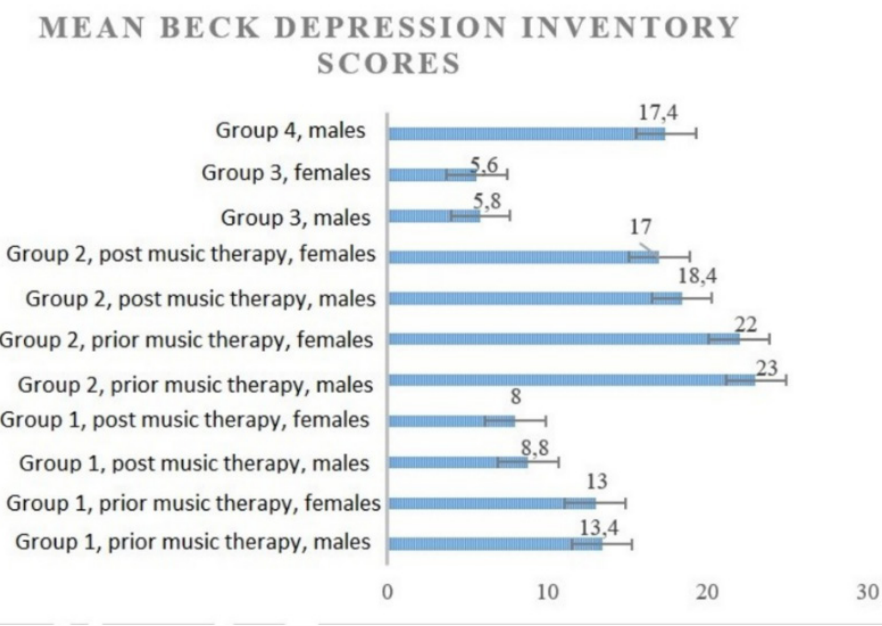

Source: Own development

There were no differences found in the mean depression scores between men and women in the control group as well as in the second and first groups before the music therapy. Significant differences were found for both men and women within the first group before and after the music therapy. While men demonstrated a 1.52-fold drop in the mean depression score $(p=0.01)$, women were showing a slightly better progress with a mean depression score that decreased 1.60 -fold $(p=0.01)$. There were no differences found between men and women within the first group after the music therapy. Men in the second group demonstrated a 1.25-fold improvement in depression level after the music therapy $(p=0.05)$, while in women, the mean depression score was 1.29 times lower, as compared to an initial score $(p=0.05)$. Within this group, no 
Classical Music Styles and Piano Therapy for Patients with Depressive Disorders Liang Du

statistically significant differences between genders were found. However, a significant difference was found between the first and second groups. For instance, men in the first group scored 2.1 times lower after treatment than those in the second group $(\mathrm{p}=0.001)$, and women scored 2.1 times lower, as compared to the second group after the music therapy. No differences in scores between genders were found. From this one may conclude that listening to music reduces the mean depression score 1.5-2-fold regardless of the listener's gender. On the other hand, music therapy is best used to people with mild depression according to Beck, as this depression level does not require the use of medication and psychiatric assistance.

Technological advances are a breeding ground for stress experiences in social individuals (CHEN, 2018). Events associated with the use of technologies are especially stressful in developed countries, where cultural heritage fades into the background or disappears completely. The range of common stress factors (high pollution and living in an information society) broadens to embrace noise pollution, exposure to electromagnetic fields from operating equipment, and so on (IRISH et al., 2006).

Music has a decisive influence on the person's emotional state and mind, as it provides emotional experience (SIMMONSSTERN et al., 2010). Aggressive and fast music that is perceived as "heavy" will press upon a person (VAN DER STEEN et al., 2017). On the contrary, calm can release positive feelings (ZHANG et al., 2017). This coincides with the present findings data. Listening to classical piano music turned to be more beneficial than listening to black metal. The main purpose of music is to reproduce the dominant emotional experiences of a person (SARKAMO et al., $2014,2015,2016)$. Hence, to shape an emotionally intelligent personality, it is necessary to timely determine dominant emotions and find a way to manage them. This will lay a foundation for the successful socialization. The impact of music is undeniable. As a means of therapy, music prevails over other types of art in terms of effectiveness (GIOVAGNOLI et al., 2018). Music therapy is either 
Classical Music Styles and Piano Therapy for Patients with Depressive Disorders Liang Du

passive (listening to music) and active (reproducing music). The active therapy is much more productive than its passive alternative but not everyone wants and/or is able to play music (ASHOORI et al., 2015). Therefore, passive therapy is a simpler solution because all patients with mild to moderate depression are able to handle it (HAN et al., 2018).

The same piece of music may evoke the opposite emotions depending on its tempo and mode. Classical music, especially piano music, helps sooth one's mind and soul (YOUNG et al., 2019). Among others, the compositions written by P. I. Tchaikovsky, e.g., Romeo and Juliet, were recognized as the most effective. Longterm and regular listening to soothing compositions helps release stress, calm down your nervous system, and, eventually, reduce the level of depression. At the psychophysiological level, listeners demonstrated an improvement in their cognitive functions as well as strengthening of synaptic connections between neurons (GIOVAGNOLI et al., 2018).

Data on other styles of music are contradictory. On the one hand, rock music can have a positive effect that is similar to that of classic music. Its heavier subgenres, however, such as black metal, can have a negative effect. When listening to intense music, individuals may experience a decrease in concentration and memory function due to the release of stress hormones. In these conditions, mental activity will generally decrease, the number of mistakes made during the cognitive routine will increase, and a feeling of overall fatigue will strike. The consequence is the development of mood disorders (SARKAMO et al., 2016). To sum up, not only music can cure depression, it also has the potential to spark a depressive disorder.

\section{Conclusions}

A significant, 1.5-2.0-fold ( $p=0.001)$, drop in the mean depression score was found in patients after exposure to classical 
Classical Music Styles and Piano Therapy for Patients with Depressive Disorders Liang Du

piano music therapy. No differences between men and women within each group were found. The mean score reported by black metal listeners, 16.7 points, was comparable with that reported by patients with moderate depression. Music therapy had a positive effect on patients in the first and second groups, reducing their levels of depression to lower cases. Patients with moderate depression turned out to be less treatable; their responses to music therapy were a 1.2 to 1.3-fold decrease in self-reporting depression scores. Given such results, listening to classical music is recommended as a means of treatment for mild depressive disorders and as an additional therapy for patients with moderate depression.

\section{References}

AALBERS, Sonja, SPREEN, Marinus, BOSVELD-VAN HAANDEL, Linda, BOGAERTS, Stefan. Evaluation of client progress in music therapy: an illustration of an N-of-1 design in individual short-term improvisational music therapy with clients with depression. Nordic Journal of Music Therapy, v. 26, v. 3, p. 256-271, 2017

ALBORNOZ, Yadira. The effects of group improvisational music therapy on depression in adolescents and adults with substance abuse: a randomized controlled trial. Nordic Journal of Music Therapy, v. 20, n. 3, p. 208-224, 2011.

AMERICAN MUSIC THERAPY ASSOCIATION. Definition of music therapy. American Music Therapy Association, 2011. Available at: http:// musictherapy.org. Accessed 12 Jul 2020.

ASHOORI, Aidin, EAGLEMAN, David M., JANKOVIC, Joseph. Effects of auditory rhythm and music on gait disturbances in Parkinson's disease. Frontiers in neurology, v. 6, p. 234, 2015.

BAGRI, Dhan Raj, GUPTA, Ashok, DUBE, Amitabh, GUPTA, Rumi K. Assessment of Examination Stress and HRV in Adolescents. National Journal of Integrated Research in Medicine, v. 7, n. 4, p. 1-7, 2016. 
Classical Music Styles and Piano Therapy for Patients with Depressive Disorders Liang Du

BEAULIEU-BOIRE, Genevieve, BOURQUE, Solange, CHAGNON, Frederic, CHOUINARD, Lucie, GALLO-PAYET, Nicole, LESUR, Olivier. Music and biological stress dampening in mechanically-ventilated patients at the intensive care unit ward-a prospective interventional randomized crossover trial. Journal of critical care, v. 28, n. 4, p. 442-450, 2013. BIDELMAN, Gavin M., ALAIN, Claude. Musical training orchestrates coordinated neuroplasticity in auditory brainstem and cortex to counteract age-related declines in categorical vowel perception. Journal of Neuroscience, v. 35, n. 3, p. 1240-1249, 2015.

BILGIÇ, Şebnem, ACAROĞLU, Rengin. Effects of listening to music on the comfort of chemotherapy patients. Western journal of nursing research, v. 39, n. 6, p. 745-762, 2017.

BOTTIROLI, Sara, ROSI, Alessia, RUSSO, Riccardo, VECCHI, Tomaso, CAVALLINI, Elena. The cognitive effects of listening to background music on older adults: processing speed improves with upbeat music, while memory seems to benefit from both upbeat and downbeat music. Frontiers in aging neuroscience, n. 6, p. 284, 2014. BRADT, Joke, DILEO, Cheryl, MAGILL, Lucanne, TEAGUE, Aaron. Music interventions for improving psychological and physical outcomes in cancer patients. Cochrane Database of Systematic Reviews, v. 8, p. CD006911. 2016.

BRO, Margrethe Langer, JESPERSEN, Kira Vibe, HANSEN, Julie Bolvig, VUUST, Peter, ABILDGAARD, Niels, GRAM, Jeppe, JOHANSEN, Christoffer. Kind of blue: A systematic review and meta-analysis of music interventions in cancer treatment. Psycho-oncology, v. 27, n. 2, p. 386400, 2018.

BUGOS, Jennifer, KOCHAR, Simran, MAXFIELD, Nathan. Intense piano training on self-efficacy and physiological stress in aging. Psychology of music, v. 44, n. 4, p. 611-624, 2016.

BUGOS, Jennifer, PERLSTEIN, William Michael, MCCRAE, Christina S., BROPHY, Timothy S., BEDENBAUGH, Purvis. Individualized piano instruction enhances executive functioning and working memory in older adults. Aging and mental health, v. 11, n. 4, p. 464-471, 2007. 
Classical Music Styles and Piano Therapy for Patients with Depressive Disorders Liang Du

CHA, Yuri, KIM, Young, HWANG, Sujin, CHUNG, Yijung. Intensive gait training with rhythmic auditory stimulation in individuals with chronic hemiparetic stroke: a pilot randomized controlled study. Neuro Rehabilitation, v. 35, n. 4, p. 681-688, 2014.

CHEN, Joyce L. Music-supported therapy for stroke motor recovery: theoretical and practical considerations. Annals of the New York Academy of Sciences, v. 1423, n. 1, p. 57-65, 2018.

CHEN, Shu-Chuan, CHOU, Cheng-Chen, CHANG, Hsiu-Ju, LIN, Mei-Feng. Comparison of group vs self-directed music interventions to reduce chemotherapy-related distress and cognitive appraisal: an exploratory study. Supportive Care in Cancer, v. 26, p. 461-469, 2018.

CONG, Fengyu, HUANG, Yixiang, KALYAKIN, Igor, LI, Hong, HUTTUNENSCOTT, Tiina, LYYTINEN, Heikki, RISTANIEMI, Tapani. Frequencyresponse-based wavelet decomposition for extracting children's mismatch negativity elicited by uninterrupted sound. Journal of Medical and Biological Engineering, v. 32, n. 3, p. 205-214, $2012 \mathrm{a}$. CONG, Fengyu, PHAN, Anh-Huy, ZHAO, Qibin, NANDI, Asoke K., ALLURI, Vinoo, TOIVIAINEN, Petri, POIKONEN, Hanna, HUOTILAINEN, Minna, CICHOCKI, Andrzej, RISTANIEMI, Tapani. Analysis of ongoing EEG elicited by natural music stimuli using nonnegative tensor factorization. Proceedings of the 20th European Signal Processing Conference (EUSIPCO), p. 494-498, 2012b.

COULTON, Simon, CLIFT, Stephen, SKINGLEY, Ann, RODRIGUEZ, John. Effectiveness and cost-effectiveness of community singing on mental health-related quality of life of older people: randomised controlled trial. The British Journal of Psychiatry, v. 207, n. 3, p. 250-255, 2015. DAYKIN, Norma, MANSFIELD, Louise, MEADS, Catherine, JULIER, Guy, TOMLINSON, Alan, PAYNE, Annette, DUFFUY, Lily Grigsby, LANE, Jack, D'LNNOCENZO, Giorgia, BURNETT, Adele, KAY, Tess, DOLAN, Paul, TESTONI, Stefano, VICTOR, Christina. What works for wellbeing? A systematic review of wellbeing outcomes for music and singing in adults. Perspectives in public health, v. 138, n. 1, p. 39-46, 2018. DESHMUKH, Abhijeet D., SARVAIYA, Avani A., SEETHALAKSHMI, Rami, NAYAK, Ajita S. Effect of Indian classical music on quality of sleep in 
Classical Music Styles and Piano Therapy for Patients with Depressive Disorders Liang Du

depressed patients: A randomized controlled trial. Nordic Journal of Music Therapy, v. 18, n. 1, p. 70-78, 2009.

DI LIBERTO, Giovanni M., O'SULLIVAN, James A., LALOR, Edmund C. Low-frequency cortical entrainment to speech reflects phoneme-level processing. Current Biology, v. 25, n. 19, p. 2457-2465, 2015.

DI LIBERTO, Giovanni M., PETER, Varghese, KALASHNIKOVA, Marina, GOSWAMI, Usha, BURNHAM, Denis, LALOR, Edmund C. Atypical cortical entrainment to speech in the right hemisphere underpins phonemic deficits in dyslexia. Neurolmage, v. 175, p. 70-79, 2018.

ENAIZAN, Odai, ZAIDAN, Ahmad A., ALWI, Nabil M., ZAIDAN, Bulat B., ALSALEM, Mohammed Assim, ALBAHRI, Omar, S., ALBAHRI, Abdurrajman S. Electronic medical record systems: Decision support examination framework for individual, security and privacy concerns using multi-perspective analysis. Health and Technology, v. 10, p. 795822, 2020.

FENG, Fan, ZHANG, Yingshi, HOU, Jun, CAl, Jiayi, JIANG, Qiyu, LI, Xiaojuan, ZHAO, Qingchun, LI, Bo-an. Can music improve sleep quality in adults with primary insomnia? A systematic review and network meta-analysis. International journal of nursing studies, v. 77, p. 189-196, 2018. FERRERI, Laura, BIGAND, Emmanuel, PERREY, Stephane, MUTHALIB, Makii, BARD, Patrick, BUGAISKA, Aurélia. Less effort, better results: how does music act on prefrontal cortex in older adults during verbal encoding? An fNIRS study. Frontiers in human neuroscience, v. 8, p. 301, 2014.

GIOVAGNOLI, Anna Rita, MANFREDI, Valentina, SCHIFANO, Letizia, PATERLINI, Chiara, PARENTE, Annalisa, TAGLIAVINI, Fabrizio. Combining drug and music therapy in patients with moderate Alzheimer's disease: a randomized study. Neurological Sciences, v. 39, p. 1021-1028, 2018. HAN, Eun Young, YUN, Ji Young, CHONG, Hyun Ju, CHOI, Kyoung-Gyu. Individual therapeutic singing program for vocal quality and depression in Parkinson's disease. Journal of movement disorders, v. 11, n. 3, p. 121, 2018. 
Classical Music Styles and Piano Therapy for Patients with Depressive Disorders Liang Du

HO, Sheau-Yan, ROHAN, Kelly J., PARENT, Justin, TAGER, Felice A., MCKINLEY, Paula S. A longitudinal study of depression, fatigue, and sleep disturbances as a symptom cluster in women with breast cancer. Journal of pain and symptom management, v. 49, n. 4, p. 707-715, 2015.

IRISH, Muireann, CUNNINGHAM, Conal, WALSH, J. Bernard, COAKLEY, Davis, LAWLOR, Brian A, ROBERTSON, Ian H., COEN, Robert F. Investigating the enhancing effect of music on autobiographical memory in mild Alzheimer's disease. Dementia and geriatric cognitive disorders, v. 22, n. 1, p. 108-120, 2006.

JORET, Marie-Eve, VAN VLIET, Marijn, CAMARRONE, Flavio, VAN HULLE, Marc M. How does the brain process mild versus strong violations in music? A pilot study using event-related potentials. 2017 22nd International Conference on Digital Signal Processing (DSP), p. 1-5, 2017.

KARVINEN, Kristina H., MURRAY, Nicholas P., ARASTU, Harry, ALLISON, Ron R. Stress reactivity, health behaviors, and compliance to medical care in breast cancer survivors. Oncology nursing forum, v. 40, n. 2, p. 149-156, 2013.

KOELSCH, Stefan. Brain correlates of music-evoked emotions. Nature Reviews Neuroscience, v. 15, n. 3, p. 170-180, 2014.

LAFÇı, Diğdem, ÖZTUNÇ, Gürsel. The effect of music on the sleep quality of breast cancer patients. International journal of caring sciences, v. 8, n. 3, p. 633, 2015.

LAI, Hui-Ling, LI, Hui-Ling, LEE, Li-Hua. Effects of music intervention with nursing presence and recorded music on psycho-physiological indices of cancer patient caregivers. Journal of clinical nursing, v. 21, n. 5-6, p. 745-756, 2012.

LIN, Mei-Feng, HSIEH, Ya-Ju, HSU, Yu-Yun, FETZER, Susan, HSU, MeiChi. A randomised controlled trial of the effect of music therapy and verbal relaxation on chemotherapy-induced anxiety. Journal of clinical nursing, v. 20, n. 7-8, p. 988-999, 2011. 
Classical Music Styles and Piano Therapy for Patients with Depressive Disorders Liang Du

MCCLEAN, Stuart, BUNT, Leslie, DAYKIN, Norma. The healing and spiritual properties of music therapy at a cancer care center. The journal of alternative and complementary medicine, v. 18, n. 4, p. 402-407, 2012.

MIASKOWSKI, Christine, BARSEVICK, Andrea, BERGER, Ann, CASAGRANDE, Rocco, GRADY, Patricia A., JACOBSEN, Paul, KUTNER, Jean, PATRICK, Donald, ZIMMERMAN, Lani, XIAO, Canhua, MATOCHA, Martha, MARDEN, Sue. Advancing symptom science through symptom cluster research: Expert panel proceedings and recommendations. JNCI: Journal of the National Cancer Institute, v. 109, n. 4, p. djw253, 2017.

MIENDLARZEWSKA, Ewa A., TROST, Wiebke J. How musical training affects cognitive development: rhythm, reward and other modulating variables. Frontiers in neuroscience, v. 7, p. 279, 2014.

NGUYEN, Janet, CRAMAROSSA, Gemma, BRUNER, Deb, CHEN, Emily, KHAN, Luluel, LEUNG, Andrew, LUTZ, Steve, CHOW, Edward. A literature review of symptom clusters in patients with breast cancer. Expert review of pharmacoeconomics \& outcomes research, v. 11, n. 5, p. 533-539, 2011.

NILSSON, Ulrica. Music: a nursing intervention. European Journal of Cardiovascular Nursing, v. 10, n. 2, p. 73-74, 2011.

ROBB, Sheri L., CARPENTER, Janet S., BURNS, Debra S. Reporting guidelines for music-based interventions. Journal of Health Psychology, v. 16, n. 2, p. 342-352, 2011

SANDADI, Samith, FRASURE, Heidi E., BRODERICK, Meredith J., WAGGONER, Steven E., MILLER, Jacqualin A., VON GRUENIGEN, Vivian E. The effect of sleep disturbance on quality of life in women with ovarian cancer. Gynecologic oncology, v. 123, n. 2, p. 351-355, 2011.

SÄRKÄMÖ, Teppoa, LAITINEN, Sarib, NUMMINEN, Avac, KURKI, Merjab, JOHNSON, Julene K.D, RANTANEN, Pekka. Cognitive, emotional, and social benefits of regular musical activities in early dementia: randomized controlled study. The Gerontologist, v. 54, n. 4, p. 634-650, 2014. 
Classical Music Styles and Piano Therapy for Patients with Depressive Disorders Liang Du

SÄRKÄMÖ, Teppoa, LAITINEN, Sarib, NUMMINEN, Avac, KURKI, Merjab, JOHNSON, Julene K.D, RANTANEN, Pekka. Clinical and demographic factors associated with the cognitive and emotional efficacy of regular musical activities in dementia. Journal of Alzheimer's Disease, v. 49, $n$. 3, p. 767-781, 2015.

SÄRKÄMÖ, Teppoa, LAITINEN, Sarib, NUMMINEN, Avac, KURKI, Merjab, JOHNSON, Julene K.D, RANTANEN, Pekka. Pattern of emotional benefits induced by regular singing and music listening in dementia. Journal of the American Geriatrics Society, v. 64, n. 2, p. 439-440, 2016.

SCHOLZ, Daniel S., ROHDE, Sönke, NIKMARAM, Nikou, BRÜCKNER, Hans-Peter, GROßBACH, Michael, ROLLNIK, Jens D., ALTENMÜLLER, Eckart O. Sonification of arm movements in stroke rehabilitation-a novel approach in neurologic music therapy. Frontiers in neurology, v. 7, p. 106, 2016.

SIHVONEN, Aleksi J., SÄRKÄMÖ, Teppo, LEO, Vera, TERVANIEMI, Mari, ALTENMÜLLER, Eckart, SOINILA, Seppo. Music-based interventions in neurological rehabilitation. The Lancet Neurology, v. 16, n. 8, p. 648660, 2017.

SIMMONS-STERN, Nicholas R., BUDSON, Andrew E., ALLY, Brandon A. Music as a memory enhancer in patients with Alzheimer's disease. Neuropsychologia, v. 48, n. 10, p. 3164-3167, 2010. STURM, Irene, DÄHNE, Sven, BLANKERTZ, Benjamin, CURIO, Gabriel. Multi-variate EEG analysis as a novel tool to examine brain responses to naturalistic music stimuli. PloS One, v. 10, n. 10, p. e0141281, 2015.

SULLIVAN, Carmen, LEUTWYLER, Heather, DUNN, Laura B., COOPER, Bruce A., PAUL, Steven M., CONLEY, Yvette P., LEVINE, Jon D., MIASKOWSKI, Christine A. Differences in symptom clusters identified using symptom occurrence rates versus severity ratings in patients with breast cancer undergoing chemotherapy. European Journal of Oncology Nursing, v. 28, p. 122-132, 2017.

SULLIVAN, Carmen, LEUTWYLER, Heather, DUNN, Laura B., COOPER, Bruce A., PAUL, Steven M., CONLEY, Yvette P., LEVINE, Jon D., MIASKOWSKI, Christine A. Stability of symptom clusters in patients with 
Classical Music Styles and Piano Therapy for Patients with Depressive Disorders Liang Du

breast cancer receiving chemotherapy. Journal of pain and symptom management, v. 55, n. 1, p. 39-55, 2018.

THORNTON, Lisa M., ANDERSEN, Barbara L., BLAKELY, Wendy P. The pain, depression, and fatigue symptom cluster in advanced breast cancer: Covariation with the hypothalamic-pituitary-adrenal axis and the sympathetic nervous system. Health Psychology, v. 29, n. 3, p. 333337, 2010.

TRIMBLE, Michael. Why humans like to cry: Tragedy, evolution, and the brain. Oxford: Oxford University Press, 2012. 232 p.

TSAI, Hsiu F., CHEN, Ying R., CHUNG, Min H., LIAO, Yuan M., CHI, Mei J., CHANG, Chia C., CHOU, Kuei R. Effectiveness of music intervention in ameliorating cancer patients' anxiety, depression, pain, and fatigue: A meta-analysis. Cancer nursing, v. 37, n. 6, p. 35-50, 2014.

VAN DER MEULEN, Ineke, VAN DE SANDT-KOENDERMAN, Mieke, HEIJENBROK-KAL, Majanka H., VISCH-BRINK, Evy G., RIBBERS, Gerard $M$. The efficacy and timing of melodic intonation therapy in subacute aphasia. Neurorehabilitation and Neural Repair, v. 28, n. 6, p. 536544, 2014.

VAN DER STEEN, Jenny T., SMALING, Hanneke J. A., VAN DER WOUDEN, Johannes C., BRUINSMA, Manon S., SCHOLTEN, Rob J. P. M., VINK, Annemiek C. Music-based therapeutic interventions for people with dementia. Cochrane Database of Systematic Reviews, v. 7, p. CD003477, 2017.

WERNER, Paul D., SWOPE, Alan J., HEIDE, Frederick J. Ethnicity, music experience, and depression. Journal of music therapy, v. 46, n. 4, p. 339-358, 2009.

WORLD HEALTH ORGANIZATION. Breast cancer: prevention and control. World Health Organization, 2018. Available at: <http://www. who.int/cancer/detection/breastcancer/en/index1.html>. Accessed on 12 Jul 2020.

YOUNG, Hui-Ju, MEHTA, Tapan S., HERMAN, Cassandra, WANG, Fuchenchu, RIMMER, James $\mathrm{H}$. The effects of M2M and adapted yoga on physical and psychosocial outcomes in people with multiple sclerosis. 
Classical Music Styles and Piano Therapy for Patients with Depressive Disorders Liang Du

Archives of physical medicine and rehabilitation, v. 100, n. 3, p. 391400, 2019.

ZENDEL, Benjamin Rich, ALAIN, Claude. Enhanced attention-dependent activity in the auditory cortex of older musicians. Neurobiology of aging, v. 35, n. 1, p. 55-63, 2014.

ZHANG, Yingshi, CAI, Jiayi, AN, Li, HUI, Fuhai, REN, Tianshu, MA, Hongda, ZHAO, Qingchun. Does music therapy enhance behavioral and cognitive function in elderly dementia patients? A systematic review and metaanalysis. Ageing research reviews, v. 35, p. 1-11, 2017.

ZHANG, Yingshi, CAl, Jiayi, ZHANG, Yaqiong, REN, Tianshu, ZHAO, Mingyi, ZHAO, Qingchun. Improvement in stroke-induced motor dysfunction by music-supported therapy: a systematic review and meta-analysis. Scientific reports, v. 6, p. 38521, 2016.

\section{Publisher}

Federal University of Goiás. School of Music and Performing Arts. Graduate Program in Music. Publication in the Portal of Periodicals UFG.

The ideas expressed in this article are the responsibility of their authors, and do not necessarily represent the opinion of the editors or the university. 